\title{
Potatoes in Ireland: Sixty years of potato research and development, market evolution and perspectives on future challenges
}

\author{
D. Griffin ${ }^{1 \dagger}$, L. Bourke ${ }^{2}$, E. Mullins ${ }^{1}$, M. Hennessy ${ }^{3}$, S. Phelan ${ }^{3}$, S. Kildea ${ }^{1}$ and D. Milbourne ${ }^{1}$
}

${ }^{1}$ Teagasc, Crops Research Department, Oak Park, Carlow, Ireland

${ }^{2}$ Bord Bia, Clanwilliam Court, Lower Mount St Dublin 2, Ireland

${ }^{3}$ Teagasc, Crops Knowledge Transfer Department, Oak Park, Carlow, Ireland

Abstract

Potato is often considered synonymous with Ireland, due to the great Irish famine in 1845, and remains the most important primary food crop in Ireland. Over the last $60 \mathrm{yr}$, the area of potatoes has reduced from 86,000 ha to 9,000 ha. This trend has occurred in most developed countries but in Ireland it is due to decreasing consumption, increasing yield, decline in seed production and potatoes no longer being use for animal feed. Significant specialisation occurred in the industry during the 1990s, with improvements in agronomy, on farm investment in storage and field equipment, consolidation of packing facilities, and a significant shift in cultivar choice, with Rooster becoming the dominant cultivar. These developments led to an increase in yield from 20 t/ha in the mid1980 s to over 40 t/ha today. Potato research in Ireland has focused on breeding, pathology and agronomy, while there have been significant changes in how knowledge is communicated to growers and the industry in this period. The industry faces many challenges in the future, largely framed by climate change, the need to reduce fertiliser and plant protection products as part of the EU Farm to Fork Strategy and industry size constraints. New superior potato varieties and novel breeding techniques will have potential to help address many challenges in combination with integrated pest management principles. Multi-actor approaches will be necessary to address all challenges but particularly to aid the industry grow and exploit emerging opportunities.

Keywords

Potato $\cdot$ market $\cdot$ breeding $\cdot$ pathology

\section{Introduction}

The potato is often considered synonymous with Ireland and more than any other crop has had a formative effect on society and the Irish economy that is felt to this day. Introduced to Europe at the end of the 16th century from South America via the Canary Islands, potato is well suited to Irish conditions and produced more food with fewer resources than cereals, leading to its widespread adoption (Bourke, 1993). The arrival of late blight (Phytophthora infestans) in 1845 (Fry et al., 1992; Griffin et al., 2002) caused the Irish potato famine with widespread loss of life and emigration (O'Grada, 1999). The potato is the third most important food crop globally and late blight still remains the most significant disease challenge to potato production in Ireland (Dowley et al., 2008) and worldwide. Data from the Central Statistics Office (CSO) reveals that in 1848 when official records began, the area of potato had reduced significantly to 258,000 ha compared to the pre-famine area due to lack of seed and confidence in the crop. The area recovered to a peak of 359,000 ha in
1858 before beginning a gradual decline to the current area of approximately 9,000 ha (Figure 1). Over this period, the potato moved from being a subsistence crop grown on almost every farm in Ireland to a high-value specialist producer cash crop.

This transition has been supported by ongoing research and development, promotions to support consumption and large changes within the industry along the supply chain to retail outlets. This paper sets out the current market situation and developments in the industry that have led to this point. The paper will review the main scientific advancements associated with the potato crop under the areas of agronomy, pathology, breeding and genetics over the last $60 \mathrm{yr}$, and the knowledge transfer mechanisms to action this information. It reviews current and imminent challenges facing the domestic crop and market, largely framed by consumer preferences, climate change and the European Green Deal. Finally, the application of new technologies and innovation strategies to underpin 


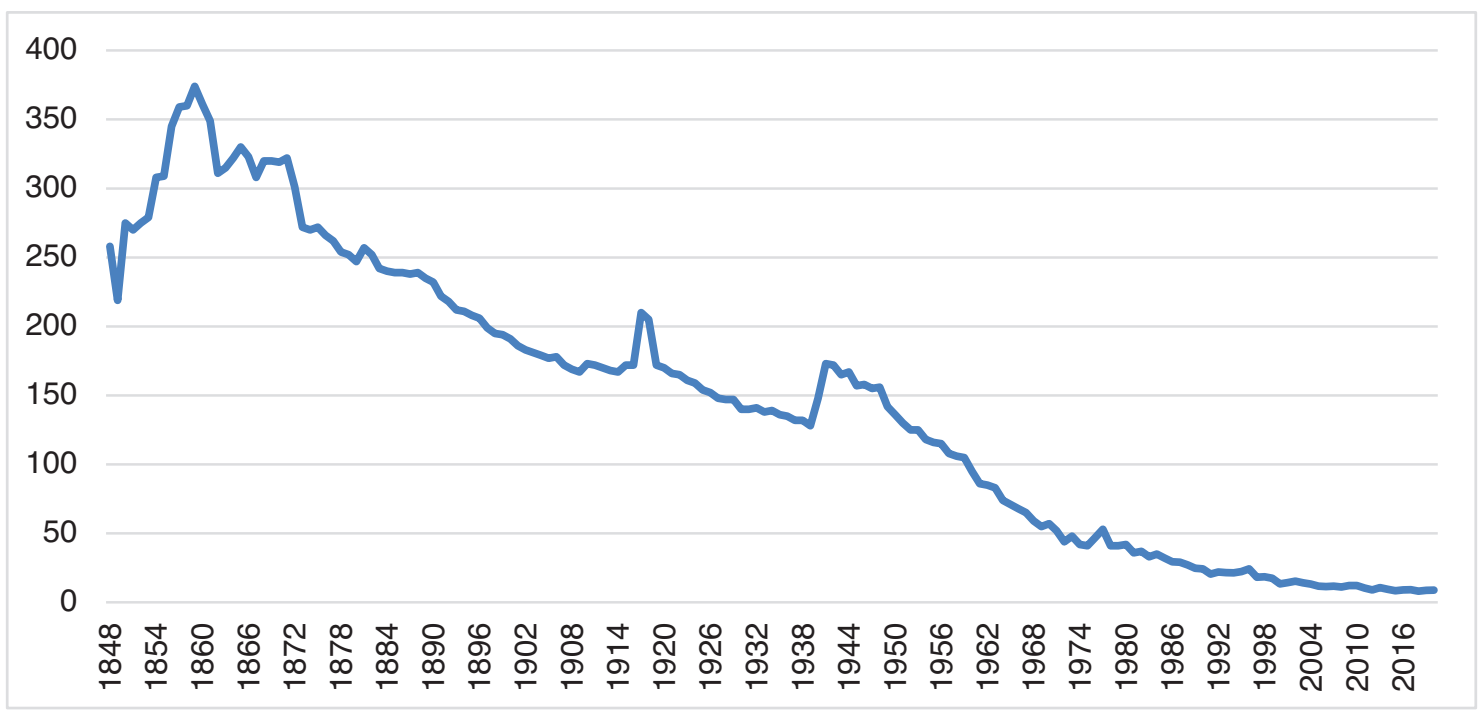

Figure 1. Area of potatoes grown in Ireland from 1848 to 2020 (000 ha).

sustainable potato production in the future to meet these challenges is discussed.

\section{Current market situation}

In 2019 , food crops accounted for almost $€ 400$ m of the total $€ 467 \mathrm{~m}$ value of horticultural crops in Ireland. The potato sector was worth almost $25 \%$ of horticulture output, valued at $€ 111 \mathrm{~m}$ at the farm-gate level. There are c. 700 Department of Agriculture, Food and the Marine (DAFM) registered potato growers in Ireland, with about 300 larger commercial farms supplying the majority of volume to retail and foodservice channels. Production was estimated to be $382,000 \mathrm{t}$ in 2019 , while the sector is focused around 10-12 central intake points for large-scale washing, selection and packing of potatoes. These potato packers supply the majority of the fresh potatoes to the retail sector. Other potato operations support foodservice "prepared" peeled/sliced potatoes, crisp manufacturing and the chip shop trade. The early potato market is another distinct market restricted to growers with suitable land and milder localised climates, whilst seed potatoes account for a small volume of the total tonnage ${ }^{1}$.

Rooster is the dominant cultivar grown for the washed and prepacked sector, representing $62 \%$ of the household purchases (based on Kantar World Panel data) and c. 58\% of plantings at the farm level (based on the 2019 annual Irish Farmers Association [IFA] survey Table 1). Consumer preference heavily influences the varieties retailed in Ireland

${ }^{1}$ https://www.kantarworldpanel.com/ie. and Kerr's Pink, Golden Wonder, British Queen and Record (Figure 2) are traditional varieties dating from the early 1900s that dominated Irish production until the late 1990s. All are high dry matter "floury" varieties with excellent taste. Before the introduction of refrigerated storage (discussed further in the following text) Home Guard, British Queen and other early varieties were traditionally marketed from late May to August, followed by Kerr's Pink and Record and finally Golden Wonder in the late season, traditionally from January/ February. Importation of new potatoes from Mediterranean countries in late spring to meet demand was common. Traditionally, potato varieties must meet both producer and consumer requirements and are difficult to displace from the market. Rooster was released in 1991 by Irish Potato Marketing Ltd. from the Teagasc potato breeding programme. It was an immediate hit with consumers as it combined taste preferences with skin finish benefits that eased preparation while being suitable for boiling, baking, chipping and mashing. As a cultivar, Rooster has excelled in this supply chain model.

\section{Early knowledge-based advancements}

Specialisation of potato growers, changes in consumer preference and advances in cultivar development

By 1961, the start of the focus period for this paper, the area of potato in Ireland was c. 86,000 ha (CSO data). The population of Ireland was beginning to urbanise and most potato production was still small scale, locally marketed and with a large proportion of the crop being used on farm for animal feed. The island of Ireland also exported a significant quantity 
Table 1: \% Potato area in Ireland by cultivar or use

\begin{tabular}{lcccccccccc}
\hline Cultivar & Rooster & $\begin{array}{c}\text { Kerr's } \\
\text { Pink }\end{array}$ & $\begin{array}{c}\text { British } \\
\text { Queen }\end{array}$ & $\begin{array}{c}\text { Golden } \\
\text { Wonder }\end{array}$ & Record & Earlies & $\begin{array}{c}\text { Fresh chip \& } \\
\text { peeling }\end{array}$ & Crisping & Salads & Whites \\
\hline \% Area 2019 & 57.8 & 6.4 & 5.8 & 2.1 & 0.6 & 0.8 & 5.8 & 11.1 & 2.7 & 6.9 \\
\hline
\end{tabular}

Source: IFA Potato Grower Survey 2019.

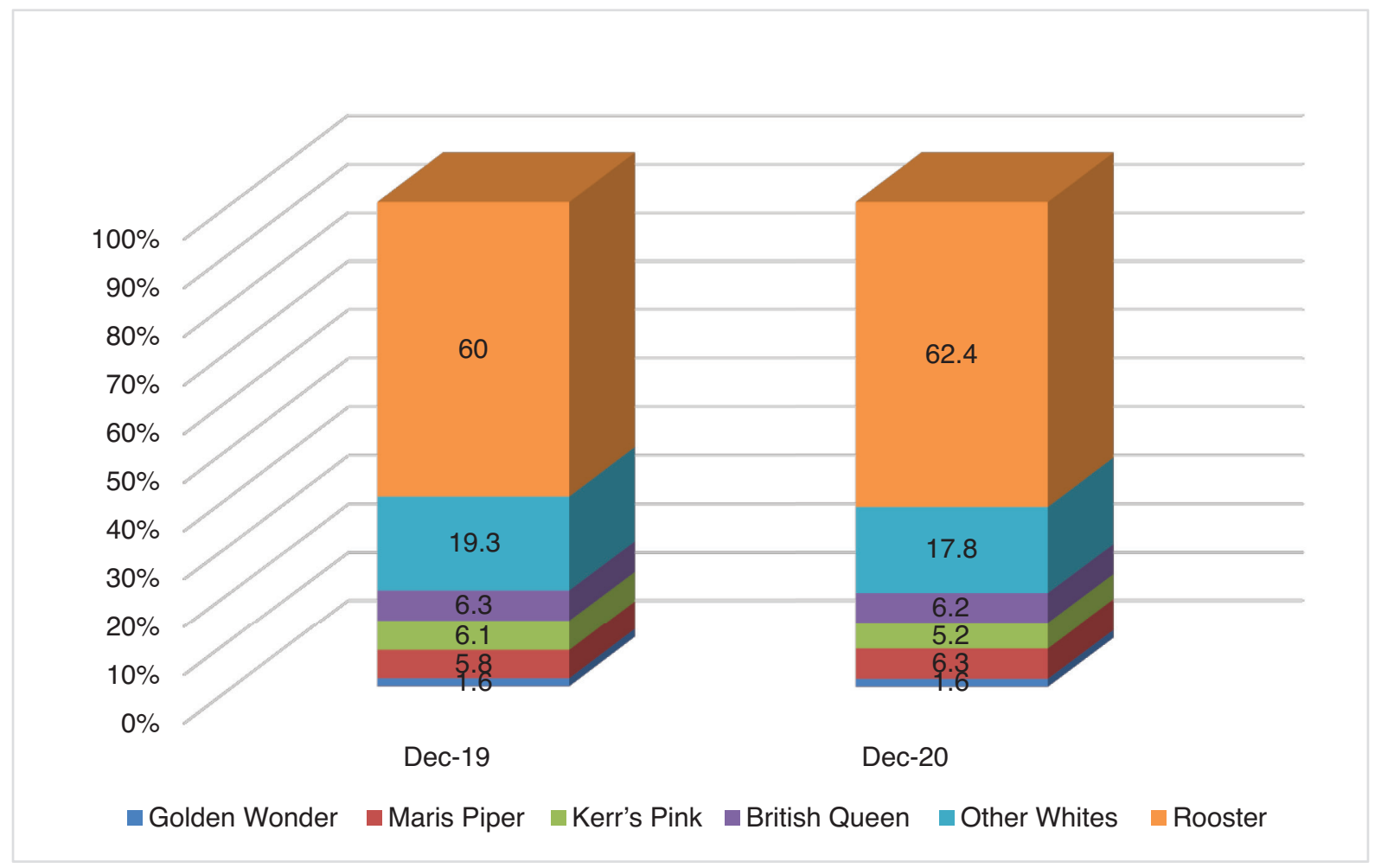

Figure 2. Proportion of Irish fresh potato market measured by household value spend for different potato varieties, figures reflect spend in $€^{\prime} 000$ by variety across all retail outlets from December 2019 to December 2020 (52 weeks) (Source: Kantar World Panel).

of seed potatoes to the Mediterranean region (Davidson, 1936; Proudfoot \& McCallum, 1961). The decline in the area of potatoes grown in Ireland over the following $60 \mathrm{yr}$ was linked with immense restructuring of the industry at both farm and retail levels, coupled with technological developments and shifts in cultivar choice which, in line with consumer preferences, increased yield and reduced production and storage losses.

Training and advice for potato farmers from the AKIS (Agricultural Knowledge Information/Innovation System) at this point was focused around general advice and awareness and it became widely accepted that state-supported agencies should ensure newer farmer practices were adopted (Keenan, 1965). Specialist advisors were deployed by the state from 1980 to act as an interface between research and advisory
(Kirley, 2008). Teagasc (a semi-state research and advisory body) was formed in 1988, with advice being delivered on a fee-paying basis. This resulted in knowledge transfer (KT) and advisory services focusing on more commercial farmers who could afford the fee (Phelan, 1995). The increased use of fertilisers and plant protection products which became part of the AKIS on many potato farms from the 1980s onwards was supported by commercial advisors or merchant agronomists. In addition, changes in the potato supply chain over this period, with a shift to supply of fresh table potatoes through supermarket chains, resulted in the necessity to produce crops to a higher specification, something that challenged growers. To support this, specialised potato farmers now use a mix of advisory services from state-funded organisations such as Teagasc, private consultants (from Ireland and the 
UK), subject matter specialists (e.g. potato storage) and also commercial advisors.

Research agronomy work conducted during this period also led to a greater understanding of potato physiology in Irish conditions particularly for new potato varieties such as Cara and Barna (Barry et al., 1990; Burke et al., 1998). Further research was also undertaken into the agronomy of producing potatoes suitable for french fry production (Burke et al., 2005). Agronomy KT to potato farmers has evolved from general to specialised advice over the past $60 \mathrm{yr}$ and this interaction continues to evolve. This level of specialisation is likely to increase as advisors in the AKIS (and farmers) are increasingly challenged to respond to environmental challenges such as decreasing chemical fertilisers and pesticides while at the same time increasing biodiversity and putting in place more environmentally friendly practices on farms.

Increased specialisation has been accompanied by a requirement for improved equipment and infrastructure. As demand for quality potatoes increased, Irish farmers looked to the UK, the Netherlands and further afield for new innovations, initially focusing on machinery, but also for changes to field agronomy practice. The introduction of centralised distribution centres by the retailers since 1998 also greatly influenced the scale and specialisation of potato producers. A major shift towards modern production techniques and market structure began in Ireland in the 1990s when the "Operational
Programme for Rural Development, Investment Aid for the Potato Sector" and FEOGA (Fonds Europeen d'Orientation et de Garantie Agricole or European Agricultural Guidance and Guarantee Fund) grant schemes were funded by the Department of Agriculture and Food. This allowed large investments in potato equipment including refrigerated stores, potato boxes, handling and packing equipment graders and field equipment (Gerry Doherty, DAFM personal communication).

The substantive changes in potato production during the period since national yield monitoring was introduced by Bord Bia and Teagasc through sample digs in 1985 are highlighted in Figure 3 (CSO). The total area of potatoes in Ireland remained relatively static from 1985 to 1996 while there was a steady increase in yield from $20 \mathrm{t} / \mathrm{ha}$ to $30 \mathrm{t} / \mathrm{ha}$. This increase in yield was largely due to better agronomy and increasing specialisation of growers. While the change in potato area planted fell from 30,000 ha in 1985 to under 9,000 ha in 2019 , the subsequent yield reduction in total annual production was not linear due to increasing yield and has fallen from over 600,000 in 1985 to between 330,000 and 400,000 t per annum currently. This reduction in production mirrors the scenario experienced in other developed countries between 1960 and 2008 , where production fell from c. 18 million ha to just over 8 million ha (with rising yields). In contrast, many developing countries are exhibiting significant growth (Haverkort et al., 2009).

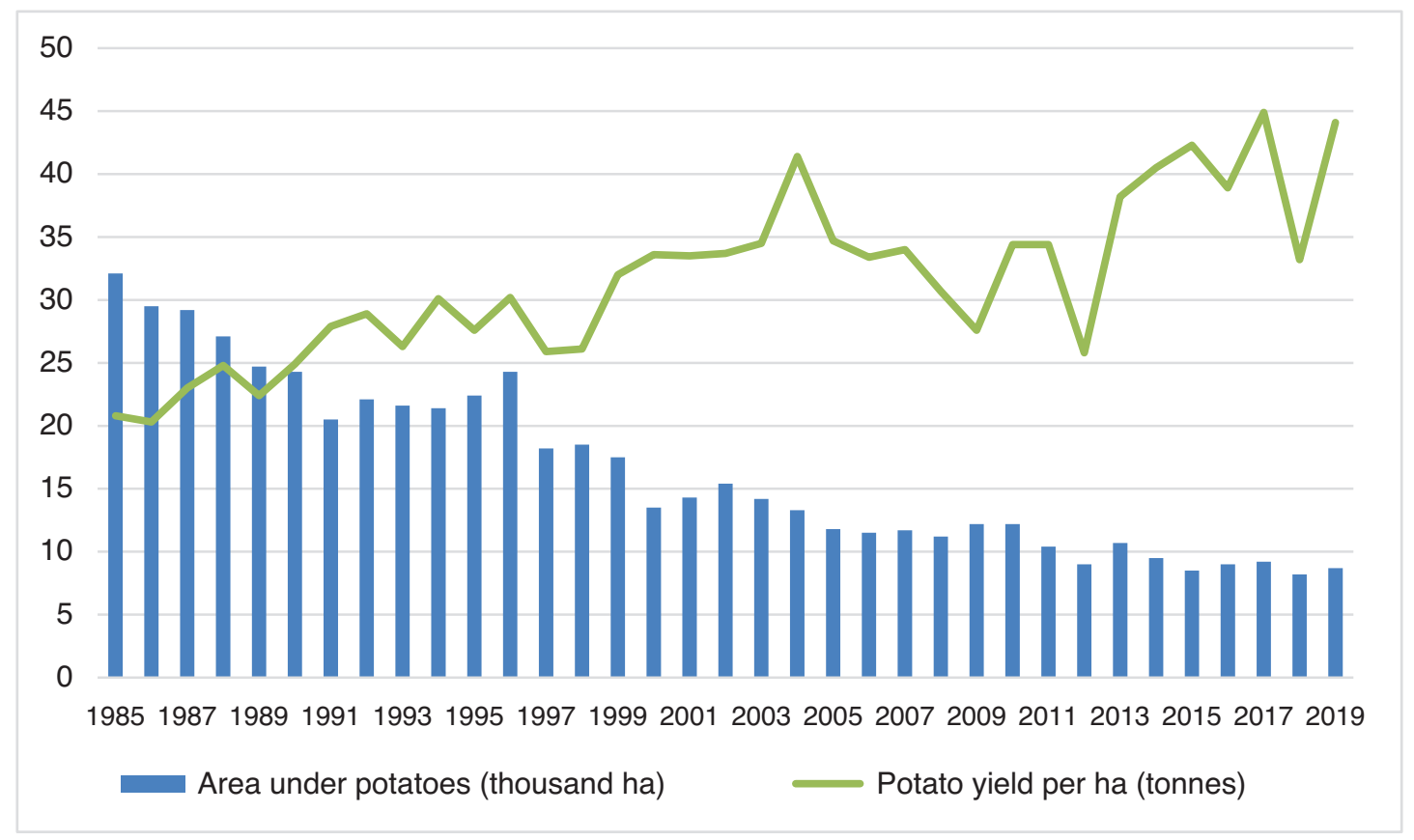

Figure 3. Area under potatoes, and average yield per hectare 1985 to 2019. 
It was gradually recognised that more modern cultivars were required to improve yield and disease resistance while still serving the preferences of the Irish consumer. The release of the cultivar Rooster, developed in response to this demand, was transformational, when coupled with the development in the industry. In the period between 2000 and 2019, the national average yield also increased to just over $40 \mathrm{t} / \mathrm{ha}$ (excluding drops in 2012 and 2018 due to severe weather events). This is largely due to the increased yield and widespread cultivation of Rooster, which increased its overall proportion of the potato area to $58 \%$ in this period. Results from the Teagasc/IPM Potato Group breeding programme breeding trials show a $20 \%$ yield increase of Rooster over Kerr's Pink, the next most popular and highest yielding cultivar in Ireland. Whilst Rooster's superior yield and disease-resistance characteristics were important features of its success, it also exhibits other traits more characteristic of modern varieties, including uniformity of size and superior skin finish. The changing market requirement for potatoes with a very good skin, which could be sold year round, gave Rooster a distinct advantage over traditional varieties. The impact of a single cultivar bred to address the specific needs of the Irish market underlined the importance of cultivar development in addressing the challenges of potato production in Ireland; this theme will be revisited later in this review.

\section{Potato research in Ireland: review and state of the art}

\section{Pathology, late blight in Ireland}

Due to the destructive potential of late blight, which is one of the few diseases that can reduce yields of untreated crops to zero, research into $P$. infestans has been fundamentally important to support production in Ireland. A review of $25 \mathrm{yr}$ of late blight trials at Teagasc Oak Park Carlow from 1983 to 2007 by Dowley et al. (2008) highlighted that losses during the period averaged to $10.1 \mathrm{t} / \mathrm{ha}$ in both marketable and total yields, representing almost $25 \%$ of potential yields in untreated crops. Research has primarily focused on three areas: $P$. infestans biology (and its relationship to disease severity and fungicide sensitivity), disease forecasting and control, and breeding for late blight resistance.

Annual monitoring of $P$. infestans populations has been a critical area of research. $P$. infestans was inadvertently introduced to Ireland and Europe over $200 \mathrm{yr}$ after its host in 1845, on imported seed potatoes from the United States (Fry et al., 1993). Similar to potato, only a fraction of the genetic diversity of the pathogen was introduced from its centre of origin leading to a single strain of blight dominating the global population (Goodwin et al., 1994). Further migrations of $P$. infestans occurred during the 1970s and 1980s. Tooley et al. (1993) showed the arrival of new strains in the late 1980s. The first population change noted was in 1981 with the emergence of phenylamide resistance (Dowley \& O'Sullivan, 1981). Two mating types (A1 and A2) of the pathogen are required for sexual reproduction. The first reports of the A2 mating type in Ireland occurred in the early 1990s, which is significant for two reasons (O'Sullivan \& Dowley, 1991; Cooke et al., 1995). Sexual hybrids of late blight can be fitter and more aggressive, and oospores, the result of sexual reproduction, can overwinter in soil, leading to the potential for early infection of healthy crops from soil. Genetic-fingerprinting studies have confirmed that the $P$. infestans population of Ireland is now a subset of the wider European population but so far have not identified sexual hybrids of $P$. infestans (Carlisle et al., 2001; Griffin et al., 2002; Stellingwerf et al., 2018).

The vast majority of commercial cultivars are late blight susceptible and heavily dependent on the use of fungicides to maintain stable yields (Cooke et al., 2011). The majority of new fungicides for blight control are very efficacious, but are only active at a single biological site, which leads to a risk of resistance development. Even in the absence of sexual reproduction, the environmental conditions that prevail in Ireland are highly conducive to the development of late blight and random mutations can arise and quickly propagate. The notable emergence of phenylamide resistance in the Irish $P$. infestans population in 1981, with the complete loss of control provided by this class of fungicides (Dowley \& O'Sullivan, 1981), was a major setback to late blight control at that time. In recent years, population monitoring has confirmed the presence of the fluazinam-resistant genotype EU_37 A2, initially detected in the Netherlands. The importance of the link of research to KT was highlighted by the fact that communication of this change to Irish growers mitigated crop losses (Schepers et al., 2018). Fungicide resistance management will be more difficult as the older multisite fungicides such as Mancozeb and Chlorothalonil have been withdrawn from the EU market where they were often used as partner products to help prevent resistance development. This highlights the necessity to continue fungicide efficacy testing and development of fungicide control programmes which takes place every year in Teagasc.

The development of late blight is highly dependent on local weather conditions, in particular temperature and relative humidity. This produces a degree of predictability that can be used as a control measure, and disease forecasting based on these parameters has been a major target for control of late blight. Disease forecasting originally developed when scope to control the disease was limited to a small number of protective fungicides per season and therefore it was important to identify periods conducive to late blight in order to maximise the utility of the timing of these applications. Bourke (1955) originally 


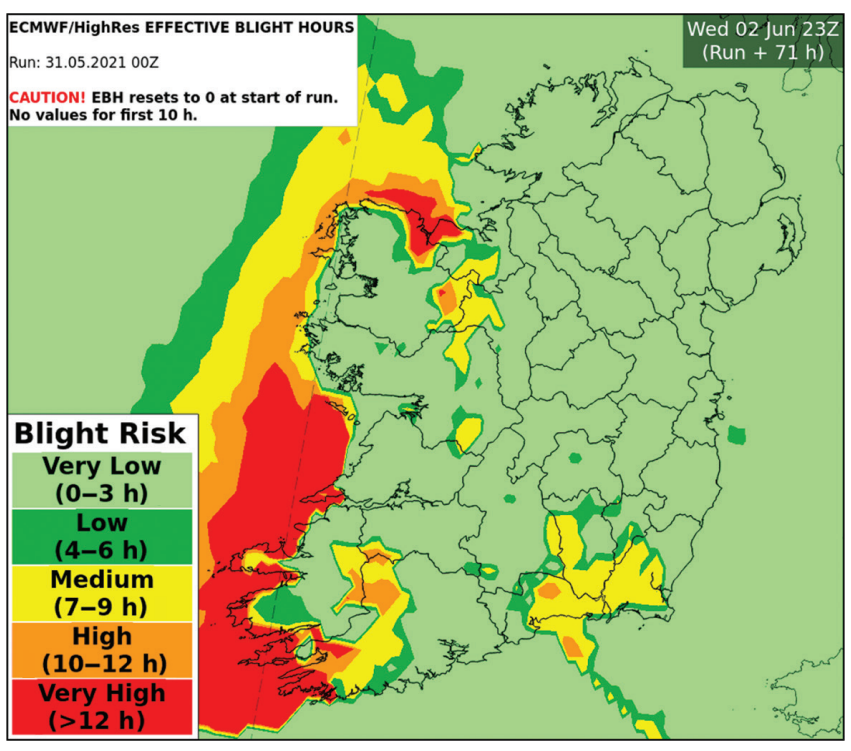

Figure 4. Sample map showing effective blight-hour risk prediction based on the revised model by Cucak et al. (2019).

developed the rules underlying late blight forecasting for Ireland, with subtle changes to these subsequently made by Keane (1982). Whilst these undoubtedly reduce the frequency and quantities of fungicides, they underestimate late blight infection events as reported by Hansen (2017) and Cucak et al. (2019). Both Leonard et al. (2001) and Cucak et al. (2021) highlight how this results in inadequate protection of the potato canopy and reductions in yield. Dowley \& Burke (2004) have demonstrated that potential does exist for the role of such forecasting or decision support systems, although the methods the authors used were based on infield weather stations which were problematic in Irish potato production given the transient nature of production. More recently, Cucak et al. (2019) have revised the rules originally developed by Bourke (1955), increasing their accuracy and predictability. It is envisioned this will be used in the future by Met Eireann to provide local disease risk assessments in a graphical map format as shown in Figure 4. These revisions were further evaluated by Cucak et al. (2021) in conjunction with an increasing emphasis of the employment of varietal resistance. This scenario, which is an important support tool for Integrated Pest Management (IPM), demonstrated that a substantial reduction in fungicide usage can be achieved without compromising disease control and yield or adversely impacting local $P$. infestans populations in terms of their aggressiveness (Cucak et al., 2019; Cucak et al., 2021).

\section{Potato virus $Y$ epidemiology}

Potato virus $\mathrm{Y}$ (PVY) remains the most important virus disease of potato globally (Valkonen, 2007). The disease is particularly problematic in seed production for certification. In recent years in Ireland it has become the dominant virus partially due to its non-persistent mode of transmission which makes it more difficult to control using insecticides and also due to newer variants of the virus emerging in Ireland which produce less visible symptoms (Hutton et al., 2015). Reports from growers suggest the virus is spreading more quickly than in the past. Hutton et al. (2013) confirmed the presence of the PVYNTN and PVYNo strains that cause potato tuber necrotic ringspot disease (PTNRD), although the tuber symptoms are rarely if ever seen due to lower temperatures exhibited in Ireland. More recently during 2017 and 2018, many recombinant PVY isolates were detected in Ireland, with PVYNTNa being the predominant genotype (Della Bartola et al., 2020). Teagasc has recently invested in a network of aphid monitoring towers at several locations across the country to aid virus prediction and aphid transmission risk for a range of agricultural and horticultural crops $^{2}$. It is envisioned this system will assist with risk prediction for PVY and other potato viruses associated with potato seed certification in the future.

\section{Cultivar development}

Potato breeding and advances in marker-assisted selection (MAS) and genomic selection (GS)

The potato breeding programme in An Foras Talúntais at Oak Park Co. Carlow was set up in 1961 to breed cultivars suitable for the domestic market with enhanced resistance to late blight. There were many plant breeding programmes in Ireland at that time including programmes in perennial ryegrass and clover breeding (which are still in existence), and now defunct programmes in cereals (DAFM) and sugar beet (An Foras Talúntais (AFT) and Irish Sugar). It soon became apparent that commercial partnership and access to diverse international markets were necessary to support a viable breeding programme. The introduction of plant variety rights (PVR) and the creation of the Union Internationale pour la Protection des Obtentions Végétales (UPOV) ${ }^{3}$ in the same year enabled breeders and holders of PVR to exclusively produce and market their new improved cultivars. The income stream generated from royalties could then be reinvested in breeding research and further cultivar development. Irish Potato Marketing Ltd. were already an established exporter of seed potatoes from Ireland and recognised the opportunity created by PVR. Informal collaboration between AFT and Irish Potato Marketing Ltd (now IPM Potato Group Ltd.) since the late 1960s developed into a formal partnership agreement in

${ }^{2}$ https://www.teagasc.ie/tillagemonth/establishing-a-bydvand-aphid-monitoring-network-/.

${ }^{3} \mathrm{http}: / / w w w . u p o v . i n t$. 
1976 and subsequently a collaboration agreement between the two parties to breed and market new potato varieties. Fifty-six cultivars have been released to date and 34 of these are either still in full commercial production or in early market development. While Rooster remains the best known cultivar in Ireland, Cara was the first successful cultivar released from the breeding programme in the early 1970s, while Nectar and Electra are well-established cutivars in the United Kingdom. Burren and Slaney are widely marketed across the Mediterranean region. This collaboration is one of the few commercially successful public-private partnerships remaining in European plant breeding.

One of the major challenges in potato breeding is the number of characteristics, or traits, that need to be combined in order to produce successful, competitive varieties that serve all of the actors along the value chain, from grower to consumer. Potato breeding involves selection of over 40 different traits, the combinations and specifications of which depend on the specific market class, use of the potato varieties and agroecology in which they will be grown (Bradshaw, 2017). In order to combine these traits, a cycle of potato breeding begins with the creation of a very large breeding population initiated when parents (generally current varieties) are crossed to produce progeny, from which one or two varieties are identified over 12-14 yr. In the Teagasc/IPM Potato Group programme, a cycle of breeding is generally initiated using approximately 200 parents, which are crossed in pairwise combinations to produce between 100,000 and 200,000 true seed progeny, each of which is a candidate cultivar (Milbourne et al., 1997). After $12 \mathrm{yr}$ of selection usually only one or two candidate cultivars remain, and these are submitted to the official trials (lasting $2 \mathrm{yr}$ ) required to gain PVR and variety status.

Potato breeding is viewed as somewhat inefficient because the number of traits that can be combined into a new cultivar in a 12-yr selection cycle is limited; for example, in the area of disease-resistance breeding. For many pests and pathogens of potato, varietal resistance is based on individual resistance genes ( $R$-genes) from cultivated and wild potato relatives from Central and South America. The cultivar Cara was an early success that was partially based on its resistance to the major strain of the potato cyst nematode (PCN) species Globodera rostochiensis in the UK at the time, conferred by the $\mathrm{H} 1$ gene from Solanum tuberosum ssp andigena.

For many plant pathogens, resistance provided by single $R$ genes is short lived. $R$-Gene breakdown due to adaptation by the pathogen population of late blight, as evidenced with Solanum demissum genes in the 1960s, led to a focus on partial "field resistance" (Malcolmson \& Black, 1966) which was thought to avoid major resistance genes and be more durable (Collins et al., 1999). The varieties Colleen (1991), Orla (1998), Setanta and Galactica (2004) are examples of cultivars released which exhibit significant levels of field resistance to late blight. However, over time, it became apparent that much field resistance was also at least partially based on $R$-genes (Gebhardt \& Valkonen, 2001). One important idea based on this increased understanding is the concept of stacking multiple $R$-genes for the same pathogen into single cultivars (Ghislain et al., 2019). Several well-known potato cultivars/lines that have exhibited durable broad-spectrum blight resistance have been shown to harbour combinations of strong and partial $R$-genes (Kim et al., 2012; Rietman et al., 2012). However, the process of introgressing $R$-genes from their wild species donors, and accumulating multiple genes in an individual cultivar over multiple selection cycles, is a multi-decadal process. Increasing the speed of recurrent selection is an important feature in resistance breeding, to enable the "stacking" of multiple $R$ genes in varieties in as short a period as possible.

The Teagasc/IPM Potato Group breeding programme has adopted a genome-based approach to overcome this limitation, using DNA-based MAS which allows tracking of beneficial genes in a breeding programme. An experimental programme for MAS was established in the period between 2004 and 2008 using a single genetic marker for a gene conferring partial resistance to the PCN (or eelworm) species Globodera pallida (Moloney et al., 2009). Currently, MAS is performed for over 20 different full and partially effective $R$ genes using the KASP genotyping platform. These markers target $R$-genes for the two major PCN species (G. pallida and $G$. rostochiensis), late blight, PVY and potato wart disease, with a general goal of adding several $R$-gene diagnostic markers to this set every year through a parallel marker development programme (Meade et al., 2020).

Most significantly, MAS can be combined with "rapid cycle breeding" approaches to help shorten the effective selection cycle and accumulate $R$-genes in high-performing cultivar candidates more quickly. There are numerous possible schemes for this, but in the Teagasc/IPM Potato Group breeding programme, the approach is to target crosses between parents with complementary $R$-genes at the beginning of every selection cycle, and to use MAS to identify progeny individuals with multiple $R$-genes in the fourth year of the 12-yr programme. These candidate varieties can then be recycled for use as parents in another round of crossing. This effectively shortens the breeding cycle to as little as 4 yr for the resistance genes under selection using MAS, and up to three cycles of selection can be performed in the same time as a single 12-yr cycle of conventional selection. This is graphically represented in Figure 5.

The recently released potato varieties Java (late blight, PVY, wart and G. rostochiensis resistant) and Buster (dual species PCN G. rostochiensis and G. pallida resistant) highlight the ability of MAS and rapid cycle breeding to speed the process of $R$-gene stacking. Buster is the result of three separate rounds of crossing, initiated in 2004, during which MAS 


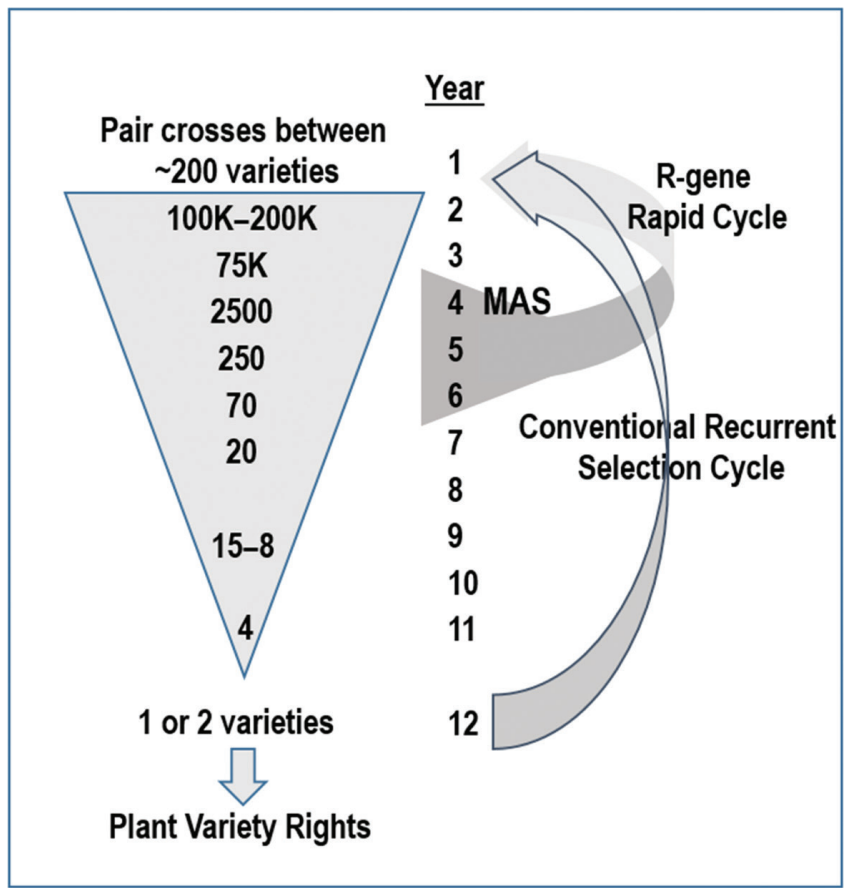

Figure 5. A representation of the Teagasc/IPM Potato Breeding Programme and how MAS and rapid cycle breeding can shorten the selection cycle. A cycle of breeding is initiated (every year) by pair crosses between approximately 200 varieties and breeding lines. The grey triangle represents the decreasing number of cultivar candidates present as selection intensifies each year. Trialling starts in one field location, and by Year 11, candidates are being trialled in Ireland, the UK, the Canaries, several locations in Europe and northern Africa. At the end of this cycle, one or two candidate varieties are advanced for PVR. In the Rapid Cycle scheme, specific crosses between $\mathrm{R}$-gene-containing varieties are incorporated into Year 1. Progeny from these crosses containing multiple R-genes are identified in Year 4. These continue through the programme, but may be recycled as parents at any time over the next several years if they perform well in the field. This shortens the selection cycle. Repeating this rapid cycling process within the conventional programme eventually yields high-performing varieties with multiple R-genes.

and rapid cycle breeding were used to stack four partially effective resistance genes to G. pallida (GpalV, Gpa5, Gpa6 and Grp1) and the $H 1$ gene into a single, high-performing cultivar. Previous research at Teagasc had demonstrated that combining the two strongest effect genes, GpalV and Gpa5, resulted in an additive effect in which very high levels of resistance to multiple field populations of $G$. pallida $\mathrm{Pa} 2 / 3$ were observed, and that MAS was an efficient way of identifying plants containing multiple genes (Dalton et al., 2013; Rigney et al., 2017). Under normal circumstances, stacking this many $R$-genes in a single cultivar over three rounds of selection could have taken in excess of $30 \mathrm{yr}$.

Many important traits in potato, such as yield, tuber quality characteristics and resistance to stresses such as drought, are under complex genetic control, influenced by the expression of many genes (polygenic). Selection for these traits suffers from similar limitations to resistance genes in terms of the speed and efficiency of the recurrent selection cycle, but MAS is not suited for identifying complex polygenic traits. This problem has been addressed in animal breeding, where practically all important traits are polygenic, by the widespread adoption of GS. First proposed by Meuwissen et al. (2001), GS is a form of MAS that uses thousands of markers across the genome to predict the likely value of traits in cultivar candidates and parents. Significantly, because marker sets scan the entire genome, traits under polygenic control can be predicted. The application of GS to potato breeding for polygenic traits in potato was modelled and it was concluded that it was potentially cost-effective, and could increase the rate of genetic gain for these traits (Slater et al., 2014; Slater et al., 2016). More recently, the application of GS for the selection of fry colour, an important trait for potatoes destined for French fry and crisp production, was successfully tested using breeding material from the Teagasc/IPM Potato Group breeding programme (Byrne et al., 2020). This study concluded that while GS has potential, the current cost of genotyping assays could limit its applicability for many breeders. Work in the potato genetics and genomics programme at Teagasc is currently focusing on the development of low-cost approaches for genotyping that will allow the benefits of GS to be applied to the breeding programme, hopefully mirroring the success of MAS.

\section{Genetic modification and novel breeding techniques}

Much of the focus on biotechnology-based approaches to augment plant breeding over the last two decades has revolved around the collective technologies that have historically been referred to as genetic modification (GM). Genetic modification is defined as the use of recombinant DNA technology to introduce DNA elements from one species into another. The approaches under this banner can be broadly divided into two categories: transgenic, and cisgenic. Transgenic refers to the insertion of genetic elements that do not occur in the species being modified (the elements either come from an unrelated species, or are engineered constructs that do not occur in nature). Cisgenic refers to the transfer of genes within a genus (e.g. from a wild potato to a cultivated potato). Both approaches are subject to regulation in the same manner and the primary EU legislation (Directive 2001/18 ${ }^{4}$ and Regulation

${ }^{4}$ Directive 2001/18/EC of the European Parliament and of the Council of 12 March 2001 on the deliberate release into the environment of genetically modified organisms and repealing Council Directive 90/220/EEC - Commission Declaration. 
$2003 / 1829^{5}$ ) governs both the cultivation and import of GM crops.

Although there has been a long history of use in a global context, the regulatory landscape and polarisation of public opinion has meant that no GM potato products have made it to market in the EU. For example, in 2010, the European Commission approved the transgenic BASF starch potato Amflora $^{\mathrm{TM}}$ that had been engineered to produce amylopectin starch, in the absence of amylose, a feature applicable to a range of industrial applications. In spite of regulatory approval, BASF pulled this GM potato from the market in 2012 due to intense political reaction ${ }^{6}$. Around the same time, BASF also ceased their commercial plans for a cisgenic GM potato, engineered with resistance to late blight. The Fortuna ${ }^{\mathrm{TM}}$ potato was based on the successful processing cultivar, Fontane, modified to contain two genes (Rpi-blb1 and Rpiblb2) from the wild species Solanum bulbocastanum, and had demonstrated strong resistance to late blight based on studies in Belgium. BASF closed down the commercialisation of Fortuna citing the uncertain regulatory environment within the EU as the primary justification for its action.

Recognising the need to demonstrate the potential societal benefits of GM technology in potato, some public sector research has adopted a more nuanced approach. From 2006 to 2015, Wageningen University in the Netherlands ran the "DuRPh" (Durable Resistance to Phytophthora infestans) Research project (Haverkort et al., 2008; Haverkort et al., 2016) which focused on developing a proof-of-concept that existing potato varieties could be made durably resistant to late blight when provided with stacked $R$-genes through cisgenic modification (Jacobsen \& Schouten, 2007). DuRPh focused not only on the production of resistant plants, but also their use in combination with IPM to develop low fungicide input control strategies for late blight. This study received broad public support (Haverkort et al., 2016) because it was publicly funded and free of commercial bias; the material was generated via cisgenics as opposed to the transgenic GM technique used previously by BASF; and most importantly because the research team actively contributed to a programme of proactive societal engagement. Hence, the generic dialogue that was standard for GM debates was countered with factual and objective commentary. As a result, the potential benefits of cisgenic GM potatoes were succinctly explained in the context of the challenge of trying to reduce fungicide inputs, while maintaining an economic return for farmers and a high-quality product for consumers.

\footnotetext{
${ }^{5}$ Regulation (EC) No 1829/2003 of the European Parliament and of the Council of 22 September 2003 on genetically modified food and feed.

${ }^{6} \mathrm{https}: / / w w w . d w . c o m / e n /$ basf-stops-gm-crop-development-ineurope/a-15671900, accessed 01.06.2021.
}

More recently, similar approaches were employed as part of the EU-funded project "Assessing and Monitoring the Impacts of Genetically-modified plants on Agroecosystems" (AMIGA). In Ireland, as part of AMIGA, Teagasc completed field evaluations of a cisgenic GM potato, developed through the DuRPh programme. The engineered potato displayed robust resistance to late blight disease through three successive seasons of field trials at Oak Park (Stellingwerf et al., 2018) with a comprehensive environmental assessment confirming there was no significant difference between the cultivation of the GM line and its non-GM comparator cultivar (Ortiz et al., 2016; Kessel et al., 2018). Indeed, using the internationally recognised and publicly available Environmental Yardstick for Pesticides to quantify the environmental impact of chemical crop protection on water life, soil life and groundwater, the cultivation of a conventional cultivar under current practice scored over 700 environmental impact points. In contrast, the cisgenic-resistant cultivar scored less than ten points (Kessel et al., 2018). As a result, the IPM control strategy adopted in the study, based on the use of the cisgenic potato line, reduced the average fungicide input by $80-90 \%$ across the three different years, without compromising control efficacy or yield. Similarly, as observed through the DuRPh project, it was evident through AMIGA that proactive public engagement ensured a greater understanding of the challenges faced by potato growers and the need to consider new technologies to reduce the environmental impact of potato production (Mullins, 2019).

In parallel to the public discussions on the applications of GMO approaches, biotechnology-based breeding initiatives have developed considerably over the last two decades. Numerous different approaches have been developed (reviewed by Schaart et al., 2016) with a diversity of technical features that make it questionable whether EU legislation originally formulated several decades ago, largely based on the features of the transgenic-based approaches of the time, is relevant and fit-for-purpose (Zimny et al., 2019; Turnbull et al., 2021).

One breeding technique called gene editing has been central to a re-evaluation of both public attitudes and current legislation. Gene editing is a set of approaches that introduce precise edits in DNA of a target genome using enzymes guided to the target site using, for example, pre-coded RNA strands. Using this type II clustered regularly interspaced short palindromic repeat (CRISPR-Cas9) system, the precision of the approach to functionally alter single/multiple genes has resulted in its rapid application by the community to address important challenges in agriculture (Chen et al., 2019). Significantly, it has been argued that when gene editing approaches simply introduce mutations in plants, they are functionally equivalent to other forms of mutagenesis breeding that are not subject to regulation, and have, in fact, formed the basis of thousands of plant varieties to date. 
In 2018, the European Court of Justice (ECJ) ruled that gene editing should be regulated as per current GMO legislation under Directive 2001/18. The ECJ judgement elicited a swift reaction from the plant science and seed trade communities in Europe due to the non-recognition of equivalence with mutagenesis breeding (Hundleby \& Harwood, 2019). The gap between the structure of EU legislation on GM approaches versus the dynamic, continuous development of novel breeding approaches by the research community was clear. Subsequently, the European Commission commenced a lengthy multi-agency study in 2019 to review the status of new breeding techniques (NBTs) under EU law. Published in April $2021^{7}$, the study concluded that current EU legislation was not fit-for-purpose and that NBTs have the potential to contribute to a more sustainable food system as part of the objectives of the European Green Deal and the Farm to Fork (F2F) Strategy. Significantly, the report followed with details outlining the pathway to commencing a consultation process with the goal of designing a new legal framework for NBTs such as gene editing and cisgenics.

The future of potato breeding is bright, but what it will look like is unclear

There are many limitations (some discussed previously) in potato breeding, arising from the genetic architecture of potato and its clonal reproduction through tubers. Biotechnologybased approaches such as MAS, GS and GM (cisgenesis and transgenesis), and gene editing overlaid on to current conventional breeding schemes are not the only approaches that are being developed to address these limitations. Diploid hybrid potato breeding, in which the genetic and reproductive architecture of potato is effectively re-engineered (using conventional breeding methods) to allow much more efficient genetic gain, was originally suggested a decade ago (Lindhout et al., 2011) and may revolutionise genetic improvement of potato in the next decade (Stokstad, 2019). The potential of this approach was recently underlined in a study by Zhang et al. (2021), who combined genome-based breeding approaches to help minimise and purge deleterious mutations from inbred lines, which were crossed to produce a hybrid line that gave plot yields equivalent to $\sim 40 \mathrm{t} / \mathrm{ha}$, which is on a par with many tetraploid cultivars. This is new technology and at the time of writing no diploid hybrid cultivar has been released. From a breeding point of view, the advantage of diploid hybrid potato is better precision and speed in cultivar development relative to current tetraploid-based breeding programmes. Hybrid potato also has another defining feature in that resulting cultivars can be propagated through true potato seed (TPS) rather than tubers. While many practical considerations

\footnotetext{
${ }^{7}$ https://ec.europa.eu/food/plant/gmo/modern_biotech/ new-genomic-techniques_en, (accessed 01.06.2021).
}

have yet to be worked out for this mode of propagation, it has potentially revolutionary ramifications for seed production. TPS is considerably less bulky than tubers and can be stored at ambient temperatures for long periods. Botanical seed is also subject to a much lower pathogen burden than seed tubers, making maintenance of seed health much easier. All of this could radically change potato seed production, and may have consequential effects on agronomy and management of potato crops. Whilst diploid hybrid breeding has great potential, its development requires a considerable investment of time and resources. Teagasc is part of a consortium with Wageningen University (The Netherlands) and other institutions and commercial potato breeders to develop an approach called Fixation-Restitution (Fix-Res) breeding, which has the potential to reduce this burden. Fix-Res breeding takes many of the advantages of diploid hybrid breeding, but makes it more compatible with current tetraploid breeding programmes, reducing its development and implementation costs.

Potato breeding is entering a period of disruptive advancement based on the development of the numerous powerful technologies and approaches that have been mentioned here. The future of genetic improvement in potato is likely to involve a combination of these approaches, and while the specific shape or shapes of these future programmes in unclear, what is clear is that breeding will be better able to respond to future challenges at exactly the time when this need is most pressing.

\section{The next 60 yr: challenges and opportunities}

The potato in industry in Ireland has changed dramatically over the last $60 \mathrm{yr}$. Specialisation of the industry, investment in technology, a reduction in the number of growers, changes in cultivars and decline in area of both seed and ware have been the most visible challenges. The next $60 \mathrm{yr}$ are likely to be equally, if not more, challenging. Climate change will impact the physical growing environment for all crops, and potato growers will have to adapt accordingly. This is reflected in policy at EU and national levels and numerous challenging policy targets have been set that will affect potato production. Finally, consumer preference continues to evolve, presenting both challenges and opportunities and this is mirrored in EU policies with an increased emphasis on holistic quality-of-life aspects of consumer citizens. The question is: how will the innovation and knowledge community in Ireland respond to support the potato industry in facing these challenges and opportunities?

\section{Predicted changes in physical climate may alter the face of potato production in Ireland}

Potato growers worldwide will encounter the effects of climate change. From an agronomic perspective, Ireland will experience more benign effects than other regions, with a 
predicted $0.5^{\circ} \mathrm{C}$ to $1^{\circ} \mathrm{C}$ of warming, drier summers and warmer wetter winters. However, weather events are predicted to be more extreme (Fealy, 2018).

Gradual and predictable changes to potato agronomy can be relatively easily accommodated. Increased summer temperatures, accompanied by drought, especially in the east of Ireland where potato production is concentrated, are an expected consequence (Holden et al., 2003). Whilst heat stress per se is unlikely to be an issue (productive potato cultivation takes place in both warmer and drier climates than those currently predicted for Ireland), there is likely to be a need for increased irrigation and drought-resistant cultivars. Some cultivars with enhanced drought or heat tolerance already exist; indeed, the Teagasc/IPM Potato Group breeding programme has a track record of producing such varieties for southern European and Northern African export markets; however, there will be a need to develop new cultivars with characteristics that suit the Irish production system and consumer preferences.

More extreme, unpredictable weather events are much more difficult to deal with. As shown in Figure 3, prolonged extreme weather patterns did affect potato yield in both 2012 (delayed planting due to very wet spring) and 2018 (prolonged drought after crop emergence in June and July), and these illustrate the potential effect of weather instability. Other potential consequences of predicted changes include crop damage due to late frosts, and wet autumns/winters that will impede harvesting, particularly on wetter soils where damage and soil loss may be an issue.

Disease control is a major component of potato production, and climate change may also impact this significantly. A small gradual change for a warmer climate in Ireland may increase the host range of several pests and pathogens of potato already present in slightly warmer neighbouring EU countries but which have not established in Ireland. The most notable of these include Colorado potato beetle (Wang et al., 2017), potato tuber moth (Phthorimaea operculella) and bacterial wilt or brown rot caused by Ralstonia solanacearum. The latter has already been shown to be moving outside its normal range to higher altitudes in both Africa (Abdurahman et al., 2017) and South America where global warming has been proposed as a cause (Castillo \& Plata, 2016).

One problem in dealing with the physical effects of climate change is addressing a complex set of events in a complex system - resulting in combinations of effects that may act as ameliorative trade-offs. For example, a corollary to the potential emergence of new pests and pathogens might be a reduction in the pressure from major existing pathogens. For instance, drier spring and summers could lead to easier and earlier plantings in Ireland and may actually ease disease pressure from late blight. In another example, increased atmospheric $\mathrm{CO}_{2}$ concentration actually has the potential to increase yields in potato production (Finnan et al., 2005), but these may be offset by lower natural precipitation. Future innovation systems to support potato production will have to be agile and responsive to the actual consequences of climate change that may or may not happen from a list of predicted possibilities.

\section{The regulatory environment to deal with climate change may make it even more challenging}

The Green Deal strategy is the EU response to climate change and environmental degradation. At the heart of this plan is to have no net emissions of greenhouse gases by 2050 , and to decouple economic growth from resource use. This strategy spans all parts of the economy across Europe ${ }^{8}$. As part of the Green Deal strategy, in May 2020, the EU published the Farm to Fork Strategy and the Biodiversity Strategy for 2030 which are particularly important for agriculture. Key targets set out in these strategies are for agriculture to have a neutral or positive environmental impact, with the ambition of reducing use and risks of pesticides by $50 \%$ and reduce fertiliser use by $20 \%$, and to increase organic agriculture to at least $25 \%$ of EU agricultural area by 2030. While potato as a food for primary consumption has a low carbon footprint of $540 \mathrm{~kg} \mathrm{CE} /$ ha per year (Hillier et al., 2009), with a relatively low water and nitrogen input in comparison to many other crops, it is still heavily reliant on plant protection products (PPPs) and fertilisers. The reduction in fertilisers and especially pesticides, if implemented in full, will have a huge impact on the potato sector. As previously discussed, Ireland's maritime climate is very conducive to potato blight and any significant reduction in these fungicides would need to be matched by improved varietal disease resistance to maintain yields and viability of the sector in Ireland.

Legislation to ameliorate the impact of agriculture is not new to potato growers. Existing national directives such as the Water Framework Directive ${ }^{9}$ and the River Basin Management ${ }^{10}$ plans are designed to protect and improve the water environment. Arable farming, including potato production, is associated with identified problems in a number of river catchments such as nitrate losses to waterways and sediment loss. Issues of bare soil, especially on sloping land, during establishment and post-harvest can give rise to overland flow of water and soil to rivers. Existing mitigation strategies such as non-cultivation buffer zones may be strengthened in years to come to mitigate the risks outlined previously. In terms of PPPs, the recent loss of diquat (used in haulm

${ }^{8} \mathrm{https} / / /$ ec.europa.eu/info/strategy/priorities-2019-2024/european-green-deal_en.

${ }^{9} \mathrm{http}: / /$ www.irishstatutebook.ie/eli/2003/si/722/made/en/ print.

${ }^{10} \mathrm{https}: / / w w w . g o v . i e / e n / p u b l i c a t i o n / 429 a 79-$ river-basin-management-plan-2018-2021/. 
destruction) and mancozeb (broad-spectrum blight control) has caused problems for which imperfect solutions have had to be implemented. For instance, the loss of diquat, with no equivalent replacement, has forced growers to use heavy equipment to top potato haulms late in the season which is not advisable where soils are saturated as damage to the growing potatoes is common in these situations as is soil damage (Phelan, 2020) ${ }^{11}$. Continuing to deal with existing regulatory changes whilst responding to the ambitious policy targets of the EU Green Deal will be a major challenge for potato growers, highlighting the importance of continuing investment in research and development to support innovative solutions to these challenges.

\section{It is not just the climate that is changing: the challenges and opportunities of evolving markets}

The potato industry has a high farm-gate value of over $€ 100$ million per annum and from a food security perspective, domestic potato production is incredibly important. The Irish sector, while specialised, profitable, technologically advanced and supplying most of our fresh consumption needs, suffers from a lack of critical mass in comparison to other agricultural enterprises due to the relatively small production area. The industry has focused on the fresh consumption markets which, due to the Irish preference for higher DM potatoes, has largely isolated the Irish market from European commodity markets for processing and seed potatoes. Across the decades, competition from other sources of carbohydrate such as rice and pasta have reduced the consumption of potatoes, not just in Ireland but in the developed world in general. As mentioned earlier, this is reflected in terms of the declining national crop production (Figure 3).

There is already a strong recognition of the need for the industry to diversify and expand to maintain viability. In recent years, notable business innovation projects in the Irish potato sector have seen some potato packer operations diversify from their traditional packing business into ready meals, alcohol and potato starch manufacturing, while several others have begun new crisp brands which require specific varieties. Further opportunities exist for the industry in the area of import substitution, particularly of chipping potatoes and baby/salad potatoes. For instance, despite Ireland's potato production capacity, over $80,000 \mathrm{t}$ of fresh potatoes for the fresh chipping market are imported each year. Theoretically, these could be produced in Ireland, but limitations include the availability of suitable, Irish-adapted chipping varieties and competition from keenly priced imports. The recent exclusion of UK seed potatoes from the EU due to Brexit (Robb, 2021) offers

\footnotetext{
${ }^{11} \mathrm{https}$ //www.teagasc.ie/media/website/crops/crops/potatoes/ Potato-newsletter-September-2020.pdf.
}

opportunities for Irish certified seed for the domestic market in the short term and possible re-invigoration of the seed export market in the medium term. Ireland is one of five high-grade seed potato regions ${ }^{12}$ due to the absence of quarantine pests and also has a large bank of virgin potato land that could be used to grow seed potatoes; however, much of this land is unavailable due to long-term leases in other farm enterprises.

\section{Conclusions: Given these challenges, where do we go from here?}

\section{Cultivars are the answer to a lot of the problems}

New cultivars can significantly contribute to the challenges across all three of the major aforementioned areas of diverse markets (such as organic and conventional), reduced PPPs and fertilisers, and biotic stress due climate change. This will be especially true if potato breeding can become faster and more precise. Breeding can address tolerance to abiotic stresses such as drought, disease and pest resistance, changing consumer preferences for products such as salad and baby potatoes, and the need for locally adapted varieties supporting all market sectors such as fresh processing and specialist markets. Potato breeding has always had the potential to deliver this in theory, but in practice, conventional potato breeding suffers from numerous limitations in terms of precision and timescale preventing the realisation of this ambition. However, as we have described in this review, we may be entering a disruptive and productive period for potato breeding. Technologies such as GS, MAS and other NBTs, combined with novel potato breeding schemes, have the potential to give breeders unprecedented levels of control in combining multiple traits in high-performing varieties. More importantly, most of these technologies increase the speed with which this can be performed, meaning that the timescale between identification of the required "ideotype" (e.g. a drought- and disease-resistant, white-skinned chipping cultivar) and the ability to produce a cultivar fitting this profile will shorten. Given that some of the impacts of climate change will become apparent over a relatively short time horizon, the ability of breeding to quickly respond to these emerging situations will be more important than ever.

While this "next-generation potato breeding" has enormous potential, there are factors that will need to be addressed to help it realise its potential. Precision breeding approaches are built on a base of basic and strategic research. Approaches such as GS, MAS and gene editing require a deeper

\footnotetext{
${ }^{12} \mathrm{https}$ //unece.org/fileadmin/DAM/trade/agr/meetings/ ge.06/2015/ExtBureauMtg_Finland/High_Grade_Region_ Finland2015.pdf.
} 
understanding of the genetic control of important target traits in order to be successfully deployed. Teagasc has a good track record in participating in multinational initiatives such as the effort to sequence the potato genome (The Potato Genome Sequencing Consortium, 2011) which has driven many of the innovations in molecular breeding worldwide. The Irish research community will need to continue to engage in these initiatives and similar precompetitive collaboration efforts to maximise their ability to effectively deploy these approaches. Given the lack of large multinational companies in potato breeding, cooperative precompetitive publicly funded research remains an important source of innovation in the potato industry (the Bioimpuls project in the Netherlands to develop late blight-resistant germplasm for organic production [Almekinders et al., 2014] is an excellent model of this type of collaborative research).

In addition to this, for NBTs such as gene editing to fulfil their potential, an aligning of regulations for these technologies to the current situation is essential. As demonstrated in AMIGA and DuRPh, cisgenesis can augment existing and new potato varieties with the ability to reduce PPP use by more than $50 \%$. The Commission's commitment to develop a new regulatory framework has to be welcomed and provides an expectation that future varieties developed through NBTs can be adopted on a case-by-case basis, supporting the EU to meet its goal of reducing the environmental impact of food production while also ensuring a stable supply of safe food for its citizens.

\section{Multi-actor approaches really are the answer}

In reality, whilst single solutions like improved cultivars are important, it is their use as a component of multi-actor approaches to address challenges facing the potato sector that has the greatest potential. We can use the specific example of management of late blight through augmented IPM to demonstrate this. As previously described, P. infestans is a dynamic pathogen capable of rapidly overcoming both cultivar resistance and PPPs. Given the added challenge of reducing the applications of fungicides by $50 \%$, how might we address control of late blight using the developments described in this review? An augmented IPM approach that was initially proposed by Kessel et al. (2018) but adapted for Irish conditions might look like the following:

(1) Rapid cycle breeding and/or other NBTs give us the potential to create durable blight-resistant varieties by stacking multiple $R$-genes from wild species in highperforming varieties.

(2) Active monitoring of $P$. infestans field populations using molecular methods, to determine the potential of strains to overcome both the $R$-genes present in varieties and the PPPs being used.

(3) Development of low spray programmes that trigger a "decision-to-spray" based on the presence of $R$-gene breaking strains in the local environment (based on $P$. infestans monitoring), combined with real-time climate data as the primary predictors of epidemic potential.

(4) Design KT support processes (e.g. cloud-based blight warning app available to registered growers) that enable growers to effectively take decisions based on these available resources.

In this model, advances in plant breeding, molecular plant pathology, modelling and data analytics are combined with well-developed KT networks to enable the challenge to be addressed. Importantly, all of this is based on the starting point of the current state of the art as outlined in previous sections. In the interim, such a model can be used with existing varieties with lower levels of resistance. Given the complexity of the challenges faced by the sector, similar multifaceted approaches combining innovations and actors across a range of disciplines will have to be developed.

\section{Climate change will be more difficult}

As previously mentioned, predicted gradual changes in climate will be gradually adapted to by the industry. However, extreme weather events which may become more common will present a greater challenge and will impact production. The Irish potato industry is highly mechanised in comparison to other countries to allow timely field operations if weather is inclement. Site and soil selection for growing may become more important in the future, both in the case of extreme weather events and also if autumns/winters become wetter, to ensure growers can avoid unsuitable heavier soils. Land access to ensure sustainable rotations particularly for seed production is currently perceived as an issue by growers. Long-term leases coupled with expansion of other agricultural areas have intensified the problem. A mechanism to make suitable land available through rotation and exchange should be explored. Continued climate prediction and horizon scanning to determine what the effects of climate change may be, such as modelling the establishment of new pest and diseases, will be key to ensuring the industry is prepared.

\section{Market development}

The Irish market is currently relatively stable in terms of demand, which has increased from a low point in 2012, attributable to two back-to-back EU-funded potato promotion campaigns $^{13}$. Opportunities to expand the industry and reduce certain imports do exist. This in turn would lead to increased critical mass, increased service and support, and investment in research and development. Innovation in this area requires a true multi-agency co-operation and strong

\footnotetext{
${ }^{13}$ www.potato.ie.
} 
partnership between public agencies and the private sector. Recent cooperative projects between Bord Bia, Teagasc and the IFA under the auspices of the Irish Potato Development Group are a good illustration of this. A good example of this is the knowledge transfer-led Salad/Baby potato project, which provided the technical know-how to produce specialist crops (Teagasc) combined with strong liaison with growers and packers (IFA) and strong market research/development (Bord Bia). The project increased production by over $200 \%{ }^{14}$ from approximately $3,000 \mathrm{t}$ per year to over $7,000 \mathrm{t}$. A current project, involving the same organisations, seeks to increase the volumes of fresh chipping potatoes grown in Ireland by developing technical expertise, engaging chip shop owners and their suppliers while creating demand for local sustainable produce. Future innovation initiatives will have to be similarly multidisciplinary, but perhaps even more ambitiously so, integrating research, KT, market development, strong partnership with private companies and growers and strong public engagement to maintain and expand a healthy and vibrant potato industry.

\section{Acknowledgements}

The authors wish to thank Carmel Hinchion, Central Statistics Office for provision of data on potato yield and planting areas in Ireland, Colm McDonnell, IPM Potato Group Ltd. and Prof. Garry Lanigan for helpful comments on the text, and Gerry Doherty, Department of Agriculture Food and the Marine for provision of information.

\section{References}

Abdurahman, A., Griffin, D., Elphinstone, J., Struik, P.C., Schulz, S., Schulte-Geldermann, E. and Sharma, K. 2017. Molecular characterization of Ralstonia solanacearum strains from Ethiopia and tracing potential source of bacterial wilt disease outbreak in seed potatoes. Plant Pathology 66: 826-834.

Almekinders, C.J.M., Mertens, L., van Loon, J.P. and Lammerts van Bueren, E.T. 2014. Potato breeding in the Netherlands: a successful participatory model with collaboration between farmers and commercial breeders. Food Security 6: 515-524.

Barry, P., Storey, T.S. and Hogan, R. 1990. Effect of plant population and set size on the seed yield of the maincrop potato variety cara. Irish Journal of Agricultural Research 29: 49-60.

Bourke, A. 1993. '“The visitation of god?' The potato and the great Irish famine". Lilliput Press Ltd, Dublin, Irish Republicx, page 230.

\footnotetext{
${ }^{14}$ https://www.teagasc.ie/media/website/publications/2019/ Teagasc-Annual-Report-2018-web.pdf.
}

Bourke, P.M.A. 1955. "The Forecasting from Weather Data of Potato Blight and Other Plant Diseases and Pests". World Meteorological Organisation.

Bradshaw, J.E. 2017. Review and analysis of limitations in ways to improve conventional potato breeding. Potato Research 60: 171-193.

Burke, J.J., Kehoe, H.W. and O'Donovan, T. 1998. The effect of set size, set population and defoliation date on seed yield of the late maincrop potato cultivar barna. Irish Journal of Agricultural and Food Research 37: 183-189.

Burke, J.J., O'Donavan, T. and Barry, P. 2005. Effect of seed source, presprouting and desiccation date on the processing quality of potato tubers for French fry production. Potato Research 48: 69-84.

Byrne, S., Meade, F., Mesiti, F., Griffin, D., Kennedy, C. and Milbourne, D. 2020. Genome-Wide Association and genomic prediction for fry color in potato. Agronomy 10: 90.

Carlisle, D.J., Cooke, L.R. and Brown, A.E. 2001. Phenotypic and genotypic characterisation of Northern Ireland isolates of Phytophthora infestans. European Journal of Plant Pathology 107: 291-303.

Castillo, J.A. and Plata, G. 2016. The expansion of brown rot disease throughout Bolivia: possible role of climate change. Canadian Journal of Microbiology 62: 442-448.

Chen, K., Wang, Y., Zhang, R., Zhang, H. and Gao, C. 2019. CRISPR/ Cas genome editing and precision plant breeding in agriculture. Annual Review of Plant Biology 70: 667-697.

Collins, A., Milbourne, D., Ramsay, L., Meyer, R., Chatot-Balandras, C., Oberhagemann, P., De Jong, W., Gebhardt, C., Bonnel, E. and Waugh, R. 1999. QTL for field resistance to late blight in potato are strongly correlated with maturity and vigour. Molecular Breeding 5: 387-398.

Cooke, L.R., Swan, R.E. and Currie, T.S. 1995. Incidence of the A2 mating type of Phytophthora infestans on potato crops in Northern Ireland. Potato Research 38: 23-29.

Cooke, L.R., Schepers, H.T.A.M., Hermansen, A., Bain, R.A., Bradshaw, N.J., Ritchie, F., Shaw, D.S., Evenhuis, A., Kessel, G.J.T., Wander, J.G.N., Andersson, B., Hansen, J.G., Hannukkala, A., Nærstad, R. and Nielsen, B.J. 2011. Epidemiology and integrated control of potato late blight in Europe. Potato Research 54: 183-222.

Cucak, M., Moral, R.A., Fealy, R., Lambkin, K. and Kildea, S. 2021. Opportunities for an improved potato late blight management in the Republic of Ireland: Field evaluation of the modified Irish Rules crop disease risk prediction model. Phytopathology 111: 1349-1360.

Cucak, M., Sparks, A., Moral, R.d.A., Kildea, S., Lambkin, K. and Fealy, R. 2019. Evaluation of the 'Irish Rules': the potato late blight forecasting model and its operational use in the Republic of Ireland. Agronomy 9: 515.

Dalton, E., Griffin, D., Gallagher, T.F., de Vetten, N. and Milbourne, D. 2013. The effect of pyramiding two potato cyst nematode 
resistance loci to Globodera pallida $\mathrm{Pa} 2 / 3$ in potato. Molecular Breeding 31: 921-930.

Davidson, W.D. 1936. The history of the potato and its progress in Ireland. Journal of the Department of Agriculture xxxiv: 3-24.

Della Bartola, M., Byrne, S. and Mullins, E. 2020. Characterization of potato virus $Y$ isolates and assessment of nanopore sequencing to detect and genotype potato viruses. Viruses 12: 478.

Dowley, L., Grant, J. and Griffin, D. 2008. Yield losses caused by late blight (Phytophthora infestans (Mont.) de Bary) in potato crops in Ireland. Irish Journal of Agricultural and Food Research 47: 69-78.

Dowley, L.J. and Burke, J.J. 2004. Field validation of four decision support systems for the control of late blight of potatoes in Ireland. Potato Research 47: 151.

Dowley, L.J. and O'Sullivan, E. 1981. Metalaxyl-resistant strains ofPhytophthora infestons (Mont.) de Bary in Ireland. Potato Research 24: 417-421.

Fealy, R., Bruyére C., Duffy, C. 2018. Regional Climate Model Simulations for Ireland for the 21st Century. Environmental Protection Agency Ireland.

Finnan, J.M., Donnelly, A., Jones, M.B. and Burke, J.I. 2005. The Effect of Elevated Levels of Carbon Dioxide on Potato Crops. Journal of Crop Improvement 13: 91-111.

Fry, W.E., Goodwin, S.B., Matuszak, J.M., Spielman, L.J., Milgroom, M.G. and Drenth, A. 1992. Population genetics and intercontinental migrations of Phytophthora infestans. Annual Review of Phytopathology 30: 107-130.

Fry, W.E., Goodwin, S.B., Dyer, A.T., Matuszak, J.M., Drenth, A., Tooley, P.W., Sujkowski, L.S., Koh, Y.J. and Cohen, B.A. 1993. Historical and recent migrations of Phytophthora infestans: Chronology, pathways, and implications. Plant Disease 77: 653-661.

Gebhardt, C. and Valkonen, J.P.T. 2001. Organization of genes controlling disease resistance in the potato genome. Annual Review of Phytopathology 39: 79-102.

Ghislain, M., Byarugaba, A.A., Magembe, E., Njoroge, A., Rivera, C., Román, M.L., Tovar, J.C., Gamboa, S., Forbes, G.A., Kreuze, J.F., Barekye, A. and Kiggundu, A. 2019. Stacking three late blight resistance genes from wild species directly into African highland potato varieties confers complete field resistance to local blight races. Plant Biotechnology Journal 17: 1119-1129.

Goodwin, S.B., Cohen, B.A. and Fry, W.E. 1994. Panglobal Distribution of a Single Clonal Lineage of the Irish Potato Famine Fungus. Proceedings of the National Academy of Sciences of the United States of America 91: 11591-11595.

Griffin, D., O'Sullivan, E., Harmey, M.A. and Dowley, L.J. 2002. DNA fingerprinting, metalaxyl resistance and mating type determination of the Phytophthora infestans population in the Republic of Ireland. Potato Research 45: 25-36.

Hansen, J.G. 2017. Integration of pathogen and host resistance information in existing DSSs_introducing the IPMBlight2.0 approach. Proceedings of the Sixteenth Euroblight Workshop. Euroblight, May pages 14-17.

Haverkort, A.J., Struik, P.C., Visser, R.G.F. and Jacobsen, E. 2009. Applied Biotechnology to Combat Late Blight in Potato Caused by Phytophthora Infestans. Potato Research 52: 249-264.

Haverkort, A.J., Boonekamp, P.M., Hutten, R., Jacobsen, E., Lotz, L.A.P., Kessel, G.J.T., Visser, R.G.F. and van der Vossen, E.A.G. 2008. Societal costs of late blight in potato and prospects of durable resistance through cisgenic modification. Potato Research 51: 47-57.

Haverkort, A.J., Boonekamp, P.M., Hutten, R., Jacobsen, E., Lotz, L.A.P., Kessel, G.J.T., Vossen, J.H. and Visser, R.G.F. 2016. Durable late blight resistance in potato through dynamic varieties obtained by cisgenesis: scientific and societal advances in the DuRPh project. Potato Research 59: 35-66.

Hillier, J., Hawes, C., Squire, G., Hilton, A., Wale, S. and Smith, P. 2009. The carbon footprints of food crop production. International Journal of Agricultural Sustainability 7: 107-118.

Holden, N.M., Brereton, A.J., Fealy, R. and Sweeney, J. 2003. Possible change in Irish climate and its impact on barley and potato yields. Agricultural and Forest Meteorology 116: 181-196.

Hundleby, P.A.C. and Harwood, W.A. 2019. Impacts of the EU GMO regulatory framework for plant genome editing. Food and Energy Security 8: e00161.

Hutton, F., Kildea, S., Griffin, D., Spink, J., Doherty, G. and Hunter, A. 2013. First report of potato tuber necrotic ringspot disease associated with PVY recombinant strains in Ireland. New Disease Reports 28: 12-12.

Hutton, F., Spink, J.H., Griffin, D., Kildea, S., Bonner, D., Doherty, G. and Hunter, A. 2015. Distribution and incidence of viruses in Irish seed potato crops. Irish Journal of Agricultural and Food Research 54: 98-106.

Jacobsen, E. and Schouten, H.J. 2007. Cisgenesis strongly improves introgression breeding and induced translocation breeding of plants. Trends Biotechnol 25: 219-223.

Keane, T. 1982. Weather and Potato Blight. Irish Meteorological Service: Dublin, Ireland.

Keenan, P.J.1965. Evaluating agricultural advisory work in Ireland. Sociologia Ruralis 5: 238-266.

Kessel, G.J.T., Mullins, E., Evenhuis, A., Stellingwerf, J., Cortes, V.O., Phelan, S., van den Bosch, T., Förch, M.G., Goedhart, P., van der Voet, H. and Lotz, L.A.P. 2018. Development and validation of IPM strategies for the cultivation of cisgenically modified late blight resistant potato. European Journal of Agronomy 96: 146-155.

Kim, H.-J., Lee, H.-R., Jo, K.-R., Mortazavian, S.M.M., Huigen, D.J., Evenhuis, B., Kessel, G., Visser, R.G.F., Jacobsen, E. and Vossen, J.H. 2012. Broad spectrum late blight resistance in potato differential set plants MaR8 and MaR9 is conferred by multiple stacked R genes. Theoretical and Applied Genetics 124: 923-935.

Kirley, T. 2008. A century of advisory services for farmers. Teagasc, Dublin. 
Leonard, R., Dowley, L.J., Rice, B. and Ward, S. 2001. Comparison of the NegFry decision support system with routine fungicide application for the control of potato late blight in Ireland. Potato Research 44: 327-336.

Lindhout, P., Meijer, D., Schotte, T., Hutten, R.C.B., Visser, R.G.F. and van Eck, H.J. 2011. Towards F1 Hybrid Seed Potato Breeding. Potato Research 54: 301-312.

Malcolmson, J.F. and Black, W. 1966. New R-genes in Solanum demissum Lindl. and their complementary races of Phytophthora infestans (Mont.) de Bary. Euphytica 15: 199-203.

Meade, F., Byrne, S., Griffin, D., Kennedy, C., Mesiti, F. and Milbourne, D. 2020. Rapid development of KASP markers for disease resistance genes using pooled whole-genome resequencing. Potato Research 63: 57-73.

Meuwissen, T.H., Hayes, B.J. and Goddard, M.E. 2001. Prediction of total genetic value using genome-wide dense marker maps. Genetics 157: 1819-1829.

Milbourne, D., Meyer, R., Bradshaw, J.E., Baird, E., Bonar, N., Provan, J., Powell, W. and Waugh, R. 1997. Comparison of PCRbased marker systems for the analysis of genetic relationships in cultivated potato. Molecular Breeding 3: 127-136.

Moloney, C., Griffin, D., Jones, P.W., Bryan, G.J., McLean, K., Bradshaw, J.E. and Milbourne, D. 2010. Development of diagnostic markers for use in breeding potatoes resistant to Globodera pallida pathotype $\mathrm{Pa} 2 / 3$ using germplasm derived from Solanum tuberosum ssp. andigena CPC 2802. Theoretical and Applied Genetics 120: 679-689.

Mullins, E. 2019. Communicating the risks of genetically modified organisms: lessons learnt from an Irish field of cisgenic potatoes. Journal of Experimental Botany 70: 3699-3703.

O'Grada, C. 1999. "Black '47 and Beyond: the Great Irish Famine in History, Economy and Memory." Princeton University Press, Woodstock Oxfordshire, United Kingdom.

O'Sullivan, E. and Dowley, L.J. 1991. A note on the occurrence of the A2 mating type and self-fertile isolates of Phytophthora infestans in the Republic of Ireland. Irish Journal of Agricultural Research 30: 67-69.

Ortiz, V., Phelan, S. and Mullins, E. 2016. A temporal assessment of nematode community structure and diversity in the rhizosphere of cisgenic Phytophthora infestans-resistant potatoes. BMC Ecology 16: $55-55$.

Phelan, J.F. 1995. Are traditional extension services dead or have they a role in rural development? European Journal of Agricultural Education and Extension 2: 7-14.

Phelan, 2020. https://www.teagasc.ie/media/website/crops/crops/ potatoes/Potato-newsletter-September-2020.pdf.

Proudfoot, K.G. and McCallum, D.J. 1961. Seed potato production in Northern Ireland. European Potato Journal 4: 330-340.

Rietman, H., Bijsterbosch, G., Cano, L.M., Lee, H.R., Vossen, J.H., Jacobsen, E., Visser, R.G., Kamoun, S. and Vleeshouwers, V.G. 2012. Qualitative and quantitative late blight resistance in the potato cultivar Sarpo Mira is determined by the perception of five distinct RXLR effectors. Molecular Plant-Microbe Interactions 25: 910-919.

Rigney, B., Blok, V., Griffin, D., Dalton, E. and Milbourne, D. 2017. Consistent action of two partially effective loci conferring resistance to Globodera pallida Pa2/3 across multiple nematode field populations. Plant Pathology 66: 1031-1040.

Robb, S. 2021. The British seed potato dilemma. Irish Farmers Journal. Irish Farm trust Ireland, Bluebell, Dublin Ireland.

Schaart, J.G., van de Wiel, C.C M., Lotz, L.A.P. and Smulders, M.J.M. 2016. Opportunities for products of new plant breeding techniques. Trends in Plant Science 21: 438-449.

Schepers, H.T.A.M., Kessel, G.J.T., Lucca, F., Förch, M.G., van den Bosch, G.B.M., Topper, C.G. and Evenhuis, A. 2018. Reduced efficacy of fluazinam against Phytophthora infestans in the Netherlands. European Journal of Plant Pathology 151: 947-960.

Slater, A.T., Cogan, N.O.I., Forster, J.W., Hayes, B.J. and Daetwyler, H.D. 2016. Improving genetic gain with genomic selection in autotetraploid potato. The Plant Genome 9: 1-15.

Slater, A.T., Cogan, N.O., Hayes, B.J., Schultz, L., Dale, M.F., Bryan, G.J. and Forster, J.W. 2014. Improving breeding efficiency in potato using molecular and quantitative genetics. Theoretical and Applied Genetics 127: 2279-2292.

Stellingwerf, J., Phelan, S., Doohan, F., Ortiz, V., Griffin, D., Bourke, A., Hutten, R., Cooke, D., Kildea, S. and Mullins, E. 2018. Evidence for selection pressure from resistant potato genotypes but not from fungicide application within a clonal Phytophthora infestans population. Plant Pathology 67: 1528-1538.

Stokstad, E. 2019. The new potato. Science 363: 574-577.

The Potato Genome Sequencing Consortium. Xu, X., Pan, S., Cheng, S., Zhang, B., Mu, D., Ni, P., Zhang, G., Yang, S., Li, R., Wang, J., Orjeda, G., Guzman, F., Torres, M., Lozano, R., Ponce, O., Martinez, D., De La Cruz, G., Chakrabarti, S.K., Patil, V.U., Skryabin, G., Kuznetsov, B.B., Ravin, N.V., Kolganova, T.V., Beletsky, A.V., Mardanov, A.V., A. Di Genova, Bolser, D.M., Martin, D.M.A., Li, G., Yang, Y., Kuang, H., Hu, Q., Xiong, X., Bishop, G.J., Sagredo, B., Mejía, N., Zagorski, W., Gromadka, R., Gawor, J., Szczesny, P., Huang, S., Zhang, Z., Liang, C., He, J., Li, Y., He, Y., Xu, J., Zhang, Y., Xie, B., Du, Y., Qu, D., Bonierbale, M., Ghislain, M., Herrera, M.D.R., Giuliano, G., Pietrella, M., Perrotta, G., Facella, P., K. O'Brien, Feingold, S.E., Barreiro, L.E., Massa, G.A., Diambra, L., Whitty, B.R., Vaillancourt, B., Lin, H., Massa, A.N., Geoffroy, M., Lundback, S., D. DellaPenna, Buell, C.R., Sharma, S.K., Marshall, D.F., Waugh, R., Bryan, G.J., Destefanis, M., Nagy, I., Milbourne, D., Thomson, S.J., Fiers, M., Jacobs, J.M.E., Nielsen, K.L., Sønderkær, M., lovene, M., Torres, G.A., Jiang, J., Veilleux, R.E., Bachem, C.W.B., J. De Boer, Borm, T., Kloosterman, B., H. Van Eck, Datema, E., Hekkert, B.L., Goverse, A., Van Ham, R.C.H.J. and Visser, R.G.F. 2011. Genome sequence and analysis of the tuber crop potato. Nature 475: 189-195.

Tooley, P. W., Therrien, C.D., Sim, J.H., Sullivan, E.O. and Dowley, L.J. 1993. Mating-type, nuclear-DNA content and isozyme genotypes 
of Irish isolates of Phytophthora infestans. Mycological Research 97: 1131-1134.

Turnbull, C., Lillemo, M. and Hvoslef-Eide, T.A.K. 2021. Global regulation of genetically modified crops amid the gene edited crop boom - a review. Frontiers in Plant Science 12: 630396.

Valkonen, J.P.T. 2007. Chapter 28 - Viruses: economical losses and biotechnological potential. In: "Potato Biology and Biotechnology", (ed. D. Vreugdenhil, et al.), Elsevier Science B.V., Amsterdam, pages 619-641.
Wang, C., Hawthorne, D., Qin, Y., Pan, X., Li, Z. and Zhu, S. 2017. Impact of climate and host availability on future distribution of Colorado potato beetle. Scientific Reports 7: 4489.

Zhang, C., Yang, Z., Tang, D., Zhu, Y., Wang, P., Li, D., Zhu, G., Xiong, X., Shang, Y., Li, C. and Huang, S. 2021. Genome design of hybrid potato. Cell 184: 3873-3883.e12.

Zimny, T., Sowa, S., Tyczewska, A. and Twardowski, T. 2019. Certain new plant breeding techniques and their marketability in the context of EU GMO legislation - recent developments. New Biotechnology 51: 49-56. 